\title{
INTERWAR AND CONTEMPORARY POLAND. A COMPARISON OF THE PROTECTION OF MINORITY RIGHTS IN THE SECOND AND IN THE THIRD POLISH REPUBLICS
}

\begin{abstract}
This paper is devoted to the problem of the protection of minority rights in Poland in the interwar period in comparison with the contemporary situation. On the one hand, before the Second World War Poland was a very heterogeneous country, inhabited for generations by multiple and internally diverse religious, national, ethnic, or linguistic minorities. On the other hand, contemporary Poland is a country in which national and ethnic minorities constitute only a few percent of the population, and the proportion of such minorities in Poland compared to other European countries is one of the lowest in Europe. The duties of the Polish authorities towards national minorities were determined by internal legal acts: decrees of the Chief of State, and above all the March Constitution and national law, as well as many international legal acts, for instance such as the socalled Little Treaty of Versailles. The second part of the paper discusses the contemporary situation of the minorities in Poland, for instance the situation of the national and ethnic minorities and the situation of sexual minorities.
\end{abstract}

\section{Keywords}

protection - minorities - March Constitution - national legislation - international law

* Dr hab. Katarzyna Witkowska-Chrzczonowicz, Professor UMK, Department of International and European Law at the Nicolaus Copernicus University in Torun, https://orcid.org/0000-0001-5165-1960, e-mail: kwch@umk.pl. 


\section{INTRODUCTION}

Interwar Poland was a country typical of the Central and Eastern Europe of the time. It was a very heterogeneous country, inhabited for generations by multiple and internally diverse religious, national, ethnic, or linguistic minorities. The multinational composition of states in this latitude after World War I was a common phenomenon. However, Poland occupied one of the first places here.

The coexistence of different nationalities was a feature of the Eastern Borderlands. ${ }^{1}$ This accounted for the remarkable cultural and social diversity of this area. It was not until the middle of the 19th century that this began to change, people started to notice these differences. In the case of many nationalities a national identity began to form in opposition to Poland and the Poles (for instance the Ukrainians) and these differences were often skilfully and perfidiously fuelled by politicians and people who counted on the benefits derived from inspiring feuds, as well as the activities of other countries (such as Bolshevik Russia).

Modern Poland, on the other hand, is a very homogeneous country in terms of nationality. This contemporary situation was influenced not only by the way the borders were drawn up after World War II, but also by the many actions associated with the Holocaust, exterminations, mass displacement, or resettlement of thousands of people after the war. Contemporary Poland is also not an example of a multicultural country because, as a post-Communist state, the country is not attractive to many immigrants. Such people treat Poland only as a "transit" country. Their destination are usually Western European countries.

${ }^{1}$ U. Wróblewska, "Polityka oświatowa państwa polskiego wobec mniejszości narodowych, grup etnicznych i wyznaniowych zamieszkujących Kresy Wschodnie w II RP", Nauka, 2011, Issue 2, p. 109, available at: http://cejsh.icm.edu.pl/cejsh/element/ bwmeta1.element.pan-n-yid-2011-iid-2-art-000000000009 [last accessed 14.7.2021]. 


\section{INTERWAR Poland and the Protection of Minority RIGHTS}

According to the 1921 census, ${ }^{2}$ Poland had a population of 27 million, of which Poles accounted for approximately $69 \%$. The most numerous national minorities were Ukrainians (14\%), Jews (8\%), Byelorussians $(3 \%)$, and Germans (3\%). However, it is difficult to determine the exact percentage figures. When the first census was conducted, the borders were still being formed. Moreover, some people, consciously or not, associated the category of nationality with the concept of citizenship. Many Jews, for instance, considered themselves "Poles of the Jewish faith".

The attitudes of the Second Polish Republic's minorities towards the Polish state also varied. For example, the Ukrainians defined their identity in opposition to the Poles. They wanted to create their independent state at the expense of Polish territories. They constituted the most numerous minority group - they lived in a dense mass on the territory of south-eastern Poland. They were usually members of the Greek Catholic or the Orthodox Church. The intelligentsia constituted about $2 \%$ of the Ukrainian community in Poland; the peasant population predominated.

The Ukrainians were a politically very active group. One of the leaders of Ukrainian nationalism, in a diplomatic conversation with a correspondent of the London Times in 1930, said clearly: "We are not striving for peace. If we allowed our people to co-operate amicably with the Poles, they would renounce the independent Ukraine which we hope to build in 30 to 40 years. Whatever is done for us, we must be dissatisfied with everything." ${ }^{3}$

Then the second minority - the Jews: they lived mostly in urban centres, but in dispersion. They constituted $21 \%$ of the total number of inhabitants of the cities of the Second Republic. Poland was the second

${ }^{2}$ Data available at: https://cbs.stat.gov.pl/ [last accessed 13.7.2021]. Cf. also: https:// spis.gov.pl/historia-spisow [last accessed 8.6.2021].

${ }^{3}$ Mniejszości narodowe II RP i konflikty na tle narodowościowym - Zintegrowana Platforma Edukacyjna, available at: https://zpe.gov.pl/a/mniejszosci-narodowe-ii-rp-ikonflikty-na-tle-narodowosciowym/DRP76tecq [last accessed 16.7.2021]. 
(after the USA) most populated country by them. They formed a diverse group, both in terms of social status and views. A significant number of Jews were in favour of preserving their distinctness of religion and customs, but proclaimed loyalty to the Polish state.

A not very numerous minority group were Byelorussians. They mainly worked in agriculture and did not have as developed a national consciousness as the Ukrainians. As a rule, they were a minority loyal to Poland, however, occasional acts of terror were committed by them, inspired by the Bolsheviks, who tried to encourage the Belarusian (and Ukrainian) population to organize protests against the representatives of the Polish authorities in the first years of the independent Polish state. They were mainly followers of the Orthodox Church.

Approximately 700 thousand Germanslived ininterwar Poland. They had enormous support from their own state. They were predominantly Protestants. Almost 70\% of the Germans were owners of large and very successful farms. They had a well-organized political and cultural life. Many organizations were active in preserving national identity and culture. Resentment towards the Polish state increased when Hitler came to power in Germany, encouraging anti-Polish activities.

As well organized as the German minority and supported by their own state, although not numerous, was the Lithuanian minority. Its situation and behaviour was largely determined by the relations between Poland and Lithuania in the interwar period. Lithuanians published their own press, managed schools and cultural and educational organizations, which served the purpose of cultivating their individuality.

The duties of the Polish authorities towards national minorities were determined by internal legal acts: decrees of the Chief of State, and above all the March Constitution, as well as international legal acts, such as the so-called Little Treaty of Versailles.

\section{National law: Protection of Minorities IN THE MARCH CONSTITUTION}

The basic legal act constituting a reference to internal legislation on the protection of the rights of national minorities was the Constitution of 
the Republic of Poland of 17 March $1921^{4}$. Of particular importance were Articles 109, 110 and 111, which were incorporated into the Constitution on the basis of the obligations arising from the Treaty for the Protection of Minorities concluded in Versailles on 28 June 1919 by Poland with the five great powers.

Article 109 guaranteed every citizen the right to "preserve their nationality and cherish their speech and national qualities". The protection of national minorities was to be ensured by the institution of "autonomous unions of minorities of a public-law character within the unions of general self-government", which were to be established by separate acts. Article 110, granted all Polish citizens belonging to "national, religious, and linguistic minorities" equal rights with other citizens to establish unions and social and charitable associations. Article 111, on the other hand, based on Article 7 of the Treaty on Minorities, provided for freedom of conscience and religion, guaranteeing protection of these rights to all inhabitants of Poland if adherence to a faith or religious rite and regulations "does not oppose public order or public morals". ${ }^{5}$ The right of religious minority churches to autonomously organize their internal religious life was guaranteed by article 115 of the Constitution.

\subsection{National law: National legislation of the Interwar Period CONCERNING THE Situation OF MinORITIES}

A wide range of issues related to religious legislation, including the affairs of minority churches, was regulated by a number of laws and regulations. ${ }^{6}$ The rights of minorities to use the national language in

${ }^{4}$ Dz. U. [Journal of Laws] of 1921, No. 44, Sec. 267.

${ }^{5}$ J. Osuchowski, Prawo wyznaniowe RP 1918-1939, Warszawa 1967, p. 244. Cf. also M. Pietrzak, Prawo wyznaniowe, Warszawa 1993, pp. 106-107.

${ }^{6}$ B. Stoczewska, Mniejszości narodowe II RP w świetle konstytucji oraz innych aktów prawnych, p. 670, available at: https://ruj.uj.edu.pl/xmlui/bitstream/handle/ item/32391/stoczewska_mniejszosci_narodowe_2016.pdf?sequence=1\&isAllowed=y [last accesseded: 14.7.2021]. See also A. Kupczyk, “Z badań nad polityką państwa polskiego wobec mniejszości narodowych i etnicznych po odzyskaniu niepodległości 11 XI 1918 roku", in M. Sadowski, A. Spychalska, K. Sadowa (eds.) Acta Erasmiana VI. Ze studiów nad prawem, administracja i ekonomia, Wrocław, 2014, p. 164, available at: https:// www.repozytorium.uni.wroc.pl/publication/49643 [last accessed 14.7.2021]. 
their relations with administrative authorities were guaranteed by language legislation.

Under Article 1 of the Act of 31 July 1924, the Polish language was recognized as the state language of the Republic of Poland. This meant that all government and self-government authorities, both in internal and external service, were to speak Polish. However, under Article 2 of this Act, Polish citizens of Ukrainian, Byelorussian, Lithuanian, and German nationalities were allowed to use their mother tongues in the areas specified by the provisions of the Act in their relations with the civil administrative authorities and offices of the first and second instance, as well as with state and local government authorities. ${ }^{7}$

The proceedings of local government bodies in the areas mentioned in the Act, as well as the minutes of these proceedings, could also be conducted and drawn up in the minority language. Also the announcements of the local self-government authorities could, based on a resolution of the given local self-government body, be drawn up in the language of a given minority. Inhabitants of Ukrainian and Belorussian nationalities in the provinces specified in the Act also had the right to address ordinary letters in their mother alphabet, i.e. in Cyrillic.

In the Law on the System of Common Courts enacted on 6 February 1928 and the Law on the Official Language of Courts, Public Prosecutor's Offices and the Notary Office of 31 July 1924, Article 2 of the Law allowed the use of Ukrainian, Belarusian, and Lithuanian in courts and public prosecutor's offices in the same areas as listed in the Law on the Official Language of Administrative Authorities. In addition, the use of these languages was allowed in the courts of appeal in Lublin and Vilnius in certain cases concerning the Volhynia and Polesie provinces. Ukrainian could also be used in the Supreme Court when this court was an appeal court against judgments and other decisions of courts located in the Lvov Court of Appeal. Both the parties and their attorneys could file all legal documents in their mother tongue. ${ }^{8}$

7 B. Stoczewska, supra note 6, p. 673.

${ }^{8}$ Regulation of the Council of Ministers' of 21st of June, 1922 concerning the abolition of the Court of Appeal of the Eastern Lands and of the arrangement of the courts in judicial districts of the Courts of Appeal in Vilnius and in Lublin (Dz. P. P. P. 1919 r. No. 14 Sec. 170) and Regulation of the Council of Ministers of 19th June 1922 (Dz. U. R. 


\subsection{INTERNATIONAL LAW}

\subsubsection{Protection of minorities guaranteed by the Little Treaty of Versailles}

Among the international treaties and conventions regulating the protection of the rights of national minorities, the most important was the Treaty for the Protection of Minorities concluded in Versailles on 28 June 1919 by Poland with the five great powers. ${ }^{9}$ Poland was obliged to grant "to all inhabitants without distinction of birth, nationality, language, race, or religion complete and total protection of life and liberty" (Article 2), to ensure them equal civil and political rights, freedom of religion and belief, and the prohibition of any restrictions on the free use of the minority language, while at the same time fulfil the need to facilitate the use of this language in the courts (Article 7). Polish citizens belonging to national minorities were to enjoy the same statutory and actual guarantees as other Polish citizens, and moreover, they were to have equal rights to establish, administer, and control at their own expense charitable, religious, and social institutions (Article 8). ${ }^{10}$ Subsequent articles contained obligations for the Polish authorities to ensure, in towns and districts inhabited by a significant fraction of citizens speaking a minority language, primary education in that language, as well as a "fair share" in the state or municipal budget (Articles 9 and 10). The Jewish minority was guaranteed the right to freely profess its religion, and in particular was guaranteed respect for the Sabbath (Article 11).

P. No. 47 Sec. 414). Cf. also P. Fiedorczyk, P. Kowalski, "Sądownictwo powszechne na terenie województwa białostockiego w II RP", Miscellanea Historico-Iuridica, 2012, vol. XI, p.283. Cf. also B. Stoczewska, supra note 6, p. 674.

9 J. Osuchowski, Uprawnienia językowe mniejszości narodowych w Rzeczypospolitej Polskiej 1918-1939, Warszawa 2000, pp. 44-50. Cf. also P. Daranowski, “Prawa mniejszości w powszechnym prawie międzynarodowym”, in D. Górecki (ed.), Sytuacja ludności polskiej na Wschodzie w świetle obowiazującego prawa i praktyki, Toruń, 2009, pp. 36-37.

${ }^{10} \mathrm{H}$. Zięba-Załucka, "Mniejszości narodowe i etniczne w Polsce", in H. Zięba-Załucka (ed.), Mniejszości narodowe i etniczne, Rzeszów, 2001, p. 22. 


\subsubsection{The Upper Silesian Convention}

Other important provisions concerning the protection of minority rights were contained in the Upper Silesian Convention, which was signed on May 15, 1922 in Geneva and hence was called the "Geneva Convention". ${ }^{11}$ After parts of Upper Silesia had been incorporated into Poland, the minority treaty of 1919 was extended to these territories. However, the provisions of the Geneva Convention extended further, especially with regard to minority education, which received most attention..$^{12}$ Inter alia, the German minority was guaranteed the right to teach in the minority language, to establish public schools and the right to establish so-called public minority schools in which the language of instruction was to be German. The needs of the minority in secondary and higher education were also satisfied.

\subsubsection{The 1921 Treaty of Riga}

The rights of the Ukrainian, Russian, and Belarusian minorities were further secured by the peace treaty between Poland, Russia, and Ukraine concluded on 18 March 1921 in Riga. ${ }^{13}$ This bilateral treaty ensured that persons belonging to the Polish minority located in Russia, Ukraine, and Belarus, and persons of Russian, Ukrainian, and Belarusian nationality living in the Polish state, had equal rights with regard to "free development of culture and language and the exercise of religious rites". These minorities were guaranteed the right, within the framework of internal legislation, to cultivate their mother tongue

${ }^{11}$ M. Maciejewski, "Prawne aspekty położenia mniejszości narodowych na Górnym Śląsku w okresie międzywojennym”, Studia Prawno-Ekonomiczne, 2014, vol. XCI (91)/1, pp. 68-69, available at: http://cejsh.icm.edu.pl/cejsh/element/bwmeta1.element.desklight-39fa7d1b-4a8a-4863-b56c-44b277b0d444?q=bwmeta1.element.desklight-63b701fc1e9b-4c28-9a43-4ea02082a617;3\&qt=CHILDREN-STATELESS [last accessed 16.7.2021].

12 B. Stoczewska, supra note 6, pp. 670-671.

13 A. Krasnowolski, Prawa mniejszości narodowych i mniejszości etnicznych w prawie międzynarodowym i polskim, Biuro Analiz i Dokumentacji. Zespół Analiz i Opracowań Tematycznych Kancelaria Senatu, 03.2011, p. 11, https://www.senat.gov.pl/ gfx/senat/pl/senatopracowania/17/plik/ot599.pdf [last accessed 14.7.2021]. 
freely, to organize education, to form associations and unions. Churches and religious associations were guaranteed the right to organize their internal functioning independently, as well as to acquire and use movable and immovable property necessary for the performance of religious rites.

Bilateral agreement on legal and financial matters gave protection of minorities. It was the Agreement between the Republic of Poland and the Czechoslovak Republic, signed in Warsaw on 23 April 1925 and valid for a period of 12 years. Most of its provisions related to education and minority language rights. ${ }^{14}$

\section{SUMMARY}

National minorities living in interwar Poland were under legal protection, which resulted from international treaties signed by Poland and from domestic legislation. The practical difficulties related to respecting the rights of minorities at that time, and the lack of consistency in creating a coherent nationality policy, resulted not only from the divergent positions on this issue presented by the main political groups. The problem of respecting the national rights of ethnic minorities was also faced by other states covered by international agreements, and was a widespread problem of that time. The main dilemma was to take measures to ensure, on the one hand, that the free development of minorities was guaranteed and that they were given effective protection, and on the other hand, to ensure that the newly-established statehood was not subjected to processes of defragmentation and decomposition due to the nationalist and separatist tendencies of the minorities in question. ${ }^{15}$

The Polish administration was not always diligent in complying with all legal acts. The lack of goodwill, the tardiness of officials or the piling up of difficulties in dealing with formalities, such as those related

\footnotetext{
14 J. Osuchowski, supra note 5, p. 51.

15 B. Stoczewska, supra note 6, p. 670.
} 
to the establishment of minority schools or cultural institutions, were not isolated cases. ${ }^{16}$ This caused tensions.

The cause of conflicts between Poles and minorities was often the fact that national divisions coincided with social divisions, while social and economic conflicts converged with national tensions.

Two positions clashed among the politicians of the Second Republic: the first granted broad autonomy to minorities, expecting them to be loyal to the state, and the second assumed Polonization and assimilation of minorities. The former stemmed from Piłsudski's concept of federation, the latter from Dmowski's vision of incorporation.

The conflicts between Poles and Ukrainians were also influenced by the unrealized promises of the Second Republic to the Ukrainian minority. For example, a Ukrainian university was not established. In those provinces where Ukrainians predominated, there was no assembly with a Polish and Ukrainian chamber, and the Ukrainian language was not recognised as the second official language alongside Polish. The Ukrainian population was reluctant to allocate plots of land in the Eastern Borderlands to Polish military personnel, participants in the fight for independence.

Despite the conflicts that arose between the authorities of the Second Republic of Poland and national minorities, there never was any formal introduction of legislation that would in any way prejudice the situation of other nations living in Poland during the interwar period.

\section{Contemporary Poland and the Protection OF MINORITY RIGHTS}

\section{The Protection of national and Ethnic Minorities}

Poland today is a country in which national and ethnic minorities constitute only a few percent of the population, and the proportion of such minorities in Poland compared to other European countries is one of the lowest in Europe. The rights of minorities and their legal

${ }^{16}$ Mniejszości narodowe II RP i konflikty na tle narodowościowym - Zintegrowana Platforma Edukacyjna, supra note 3. 
status are currently regulated by the 1997 Constitution of the Republic of Poland, in particular Article 35, which guarantees Polish citizens belonging to national and ethnic minorities the freedom to maintain and develop their own language and culture, preserve customs and traditions. Moreover, the Constitution provides national and ethnic minorities with the right to establish their own educational and cultural institutions and institutions for the protection of their religious identity, as well as the right to participate in the settlement of matters concerning their cultural identity.

Furthermore, the status of minorities is regulated by the Law of 6 January 2005 on National and Ethnic Minorities and Regional Language. ${ }^{17}$ The Act distinguishes the following minorities: Belarusian, Czech, Lithuanian, German, Armenian, Russian, Slovak, Ukrainian, and Jewish, while Article 2(4) of the Act lists the minorities regarded as ethnic minorities within its meaning: Karaite, Lemko, Roma, and Tatar. Furthermore, Article 19(2) of the Act defines Kashubian as a regional language.

The aforementioned Act contains a definition of national and ethnic minorities and introduces, inter alia, the possibility of using the minority language as a supporting language before the municipal authorities, as well as the possibility of using additional traditional names in the minority language alongside the official names of localities and physiographic objects and street names. The law imposes on public authorities the obligation to take appropriate measures to support activities aimed at protecting, preserving, and developing the cultural identity of minorities. It also enables the award of targeted and subjective grants to minorities.

In addition, relevant is the Act of 5 January 2011 on the Electoral Code $^{18}$ which provides for the exemption of electoral committees

17 A. Malicka, „Status prawny mniejszości narodowych i etnicznych w Polsce - ustawa o mniejszościach narodowych i etnicznych oraz języku regionalnym" in J. B. Banach-Guiterrez, M. Jabłoński (eds.), Aktualne problemy ochrony wolności i praw mniejszości w Polsce i na świecie, Wrocław, 2017, p. 56, available at: http://www.bibliotekacyfrowa.pl/Content/79764/Aktualne_problemy_ochrony_wolnosci_i_praw.pdf [last accessed 14.7.2021].

18 Podstawowe prawa, Zapisy z Konstytucji Rzeczypospolitej Polskiej i właściwych ustaw - Mniejszości Narodowe i Etniczne, available at: http://mniejszosci.narodowe.mswia. 
established by national minority organizations from the requirement to exceed the 5\% electoral threshold.

The Act of 7 October 1999 on the Polish language, in turn, contains a declaration that its provisions do not violate the rights of national and ethnic minorities. On its basis, the Regulation of the Minister of Internal Affairs and Administration of 18 March 2002 was issued on the cases in which the names and texts in Polish may be accompanied by versions translated into a foreign language.

Another act regulating the status of minorities is the Act of 7 September 1991 on the Educational System, which stipulates that public schools and institutions should enable students to maintain their sense of national, ethnic, linguistic, and religious identity, and in particular to learn their language and their own history and culture, and the Act of 29 December 1992 on Radio and Television, which stipulates that public radio and television programmes should take into account the needs of national and ethnic minorities.

In addition, the Polish Penal Code provides for the criminalization of ethnically motivated crimes, and the Codes of Procedure - administrative, civil and criminal - allow members of minorities to be assisted by interpreters.

The Act of 29 August 1997 on the protection of personal data, however, prohibits - with the exception of a list of enumerated situations the processing of data revealing ethnic origin.

The fundamental rights of national minorities, guaranteed by Polish law, include: the prohibition of discrimination and the prohibition of organizations whose programme or activities presuppose or condone racial and national hatred. Minorities in Poland are guaranteed the freedom to preserve and develop their own language; the freedom to preserve customs and traditions, and to develop their own culture; the right to education in the minority language; the right to unrestricted opportunity to practise their religion; the right to establish their own educational, cultural, and religious institutions; the right to participate in decisions on matters concerning their national identity; electoral preferences for election committees of minority organizations. 
It is worth mentioning that many Polish citizens, and residents of Upper Silesia, have for many years declared a Silesian nationality separate from the Polish, German, Czech, and Slovakian nationalities. In the 2011 census, over 800000 people declared their affiliation to this nationality. The 2021 Census is currently taking place in Poland, and the Silesian Autonomy Movement supports Silesians in declaring their Silesian nationality ${ }^{19}$ and using the Silesian language. It is interesting to note that one of the Silesian MEPs recently addressed the European Parliament in Silesian and regrettably the interpreter failed to convey the presented message. ${ }^{20}$ The speech was intended to draw the attention of MEPs to the disregard of Silesians by the current Polish authorities, who claim that "there is no such nationality as Silesian, and its declaration is a camouflaged German option".

\section{The Status of Sexual Minorities}

The most visible problem in contemporary Poland, however, is the status of sexual minorities, whose rights, compared to the countries of Western Europe, are limited (there is no possibility to enter into civil partnerships or same-sex marriages).

In last year's election campaign, the then victorious candidate, the current President of Poland Andrzej Duda, said that "LGBT are not people, but ideology". ${ }^{21}$ In Poland, there is no systematic sexual education of children and young people, but only the very conservative course called "upbringing to family life".

In 2020, the total of regions where the Local Government Charter of Family Rights or a resolution establishing an LGBT-free zone had been

19 Spis Powszechny 2021. Jak zadeklarować narodowość śląską? Ćwierć wieku walki Ruchu Autonomii Śląska o uznanie śląskiej tożsamości, 29.3.2021, available at: https:// spis-powszechny.pl/cwierc-wieku-walki-ruchu-autonomii-slaska-o-uznanie-slaskiejtozsamosci/ [last accessed 18.7.2021].

${ }^{20}$ A. Czesak, Łukasz Kohout po śląsku w PE, 18.12.2020, available at: https://www. youtube.com/watch?v=aZ4RjJ3TOmw, [last accessed 14.7.2021].

${ }^{21}$ P. Malinowski, Andrzej Duda o LGBT: Próbują wmówić, że to ludzie. To ideologia, 13.3.2020, available at: https://www.rp.pl/Wybory-prezydenckie-2020/200619782Andrzej-Duda-o-LGBT-Probuja-wmowic-ze-to-ludzie-To-ideologia.html [last accessed 19.7.2021]. 
adopted covered more than $30 \%$ of Poland's territory, ${ }^{22}$ however, these resolutions have no legal force, but only a symbolic meaning.

In a sense, however, they have given homophobia some official status and local government councillors interpret it de facto as a basis for discrimination. The European Parliament, in its 2019 resolution, ${ }^{23}$ stated that "the creation of LGBT-free zones, even if it does not involve the introduction of physical barriers, is an extremely discriminatory measure that restricts the freedom of movement of EU citizens".

The European Union reacted robustly to these resolutions by some Polish local authorities on 28 July 2020, when EU Equality Commissioner Helena Dalli announced that 6 applications for grants under the "Town Twinning" action of the European Commission's Europe for Citizens programme had been rejected because of the adoption of resolutions "on LGBT-free zones or on family rights". ${ }^{24}$ Compensation for the lack of these funds was announced by the Polish Minister of Justice Zbigniew Ziobro. ${ }^{25}$

${ }^{22}$ K. Jabłonowski, Strefy “wolne od ideologii LGBT”: ponad 50 samorządów przyjęło podobne uchwały, 30.9.2020, available at: https://konkret24.tvn24.pl/polska,108/strefywolne-od-ideologii-lgbt-ponad-50-samorzadow-przyjelo-podobne-uchwaly,1031974. html [last accessed 18.7.2021].

${ }^{23}$ Resolution on public discrimination and hate speech against LGBTI people, including LGBTI free, 2019/2933(RSP), available at: https://oeil.secure.europarl.europa. eu/oeil/popups/ficheprocedure.do?lang=en\&reference=2019/2933(RSP) [last accessed 19.7.2021]. See also: PE przyjąt rezolucję: Unia Europejska strefą wolności osób LGBTIQ. Komunikat Biura RPO Rzecznik Praw Obywatelskich, available at: https://bip.brpo.gov.pl/pl/content/pe-rezolucja-unia-europejska-strefa-wolnosci-osob-lgbtiq-komunikat-biura-rpo [last accessed 19.7.2021].

24 P. Orlikowski, Unijna komisarz kontra "strefy wolne od LGBT". Nie będzie pieniędzy dla polskich miast, 28.7.2020, available at: https://www.money.pl/gospodarka/ unijna-komisarz-kontra-strefy-wolne-od-lgbt-nie-bedzie-pieniedzy-dla-polskich-miast6537048606554241a.html [last accessed 18.7.2021].

${ }^{25}$ M. Kośka, "Gminy wolne od LGBT" ukarane przez UE za dyskryminowanie mniejszości. Dostaną jednak pieniądze z Funduszu Sprawiedliwości, 18.8.2020, available at: https://www.money.pl/gospodarka/gminy-wolne-od-lgbt-ukarane-przez-ue-zadyskryminowanie-mniejszosci-dostana-jednak-pieniadze-z -funduszu-sprawiedliwosci6544359641200769a.html [last accessed 18.7.2021]. 


\section{WOMEN RIGHTS}

The final problem to which I would like to draw attention is the current issue of women's rights, especially the rights of those women from poorer backgrounds. On 22 October 2020, the Polish Constitutional Tribunal handed down a judgment ${ }^{26}$ in which it declared unconstitutional one of the three grounds for legal abortion in Poland, holding that a provision which permits termination of pregnancy when prenatal tests or other medical grounds indicate a high probability of severe and irreversible foetal disability or incurable disease, is contrary to the constitution. The Polish Constitutional Tribunal has therefore forced Polish women to give birth to seriously ill and damaged children, including those with lethal defects.

It is estimated that, hitherto, these were the premises of approximately $90 \%$ of legal abortions in Poland. In practice, two grounds for legal abortion in Poland remain: when pregnancy threatens the life or health of a woman or when there is a justified suspicion that the pregnancy is the result of a prohibited act. This decision is a breach of a social compromise made in 1993 and has caused numerous social protests, despite the pandemic. The judgment is most damaging to women who are not wealthy, because those who are more financially well off simply travel en masse to the neighbouring Czech Republic or even to clinics in London to undergo such procedures, which are strictly regulated by Polish law. In Poland there is also a flourishing abortion underground which offers treatments under very diverse conditions, often dangerous to women's health.

\section{CONCLUSIONS}

Interwar Poland and Poland in the third decade of the 21st century are two separate worlds in terms of minority protection. National, religious, and linguistic minorities were very visible in interwar Poland. People

${ }^{26}$ See case K 1/20, judgment of the CT of 22nd of October, 2020. 
functioned well within local communities. The conflicts were mainly fuelled by politicians.

Many Poles have a "mixture" of nationalities, religious denominations, and all sorts of otherness in their family history. For centuries, Poland was a bastion of tolerance, especially when religious wars, counter-reformation, night massacres on a massive scale, and persecution of non-believers raged in the countries of Western Europe. I believe that this beautiful tradition, rooted in our hearts, will, in the long term, make it possible to build Poland as a state free of discrimination, xenophobia, and fear of otherness of any kind. 